\title{
Chronic active hepatitis
}

\author{
P J Johnson, I G McFarlane
}

By 1970, significant numbers of patients with a syndrome that had become variously known as 'active chronic hepatitis', 'chronic aggressive hepatitis', or 'chronic active liver disease', were being referred to the Liver Unit.

The first description of this condition, predominantly affecting women and characterised by fluctuating jaundice, arthralgia and myalgia, hepatosplenomegaly, amenorrhoea, acneform rashes, and hypergammaglobulinaemia, is generally attributed to Waldenstrom in $1950,{ }^{1}$ but it seems likely that the syndrome was recognised much earlier. ${ }^{23}$ What is beyond doubt is that it was considered to be a particularly aggressive disorder, with early reports indicating up to $80 \%$ mortality at five years ${ }^{45}$ and later prospective studies suggesting that up to $40 \%$ might die within six months of diagnosis. ${ }^{6}$

Not surprisingly, treatment of the condition became a hepatological priority. In the late 1950's reports had begun to appear associating the disorder with systemic lupus erythematosus $^{7-11}$ - leading Ian Mackay working at the Walter and Eliza Hall Institute, Melbourne to coin the term 'lupoid hepatitis' ${ }^{8}$ This association with a disease that was one of the earliest to be recognised as an autoimmune condition led to searches for further markers of disordered immunity and evidence of other abnormalities was soon forthcoming, ${ }^{1213}$ including seminal papers on circulating smooth muscle autoantibodies by Senga Whittingham, ${ }^{14}{ }^{15}$ who had just begun what was to be a long and fruitful collaboration with Ian Mackay, and Deborah Doniach $^{16}$ (who was later to provide us with so much help and encouragement). It was at this time that the term 'autoimmune' hepatitis first began to appear, ${ }^{14} 15$ and the increasing evidence that this might be a condition of disordered immunity led to the first attempts at treatment with immunosuppressive drugs. ${ }^{17} 18$

These first trials showed that therapy with 6-mercaptopurine, the metabolic derivative of azathioprine, could improve the clinical, biochemical and histological manifestations of the disease, but did not markedly affect the hypergammaglobulinaemia, ${ }^{1718}$ and it was subsequently shown that azathioprine used alone could not induce remission. ${ }^{19}$ In a trial with a fixed dose (10 mg/day) of another immunosuppressive agent, prednisone, The Copenhagen Study Group for Liver Diseases ${ }^{20}$ found no improvement in survival ( $45 \%$ at four years and $20 \%$ at eight years) among a large group of patients with cirrhosis. A trial from the Royal Free Hospital, however, suggested that prednisolone was effective ${ }^{21}$ and reanalysis of the Copenhagen data later suggested that a subgroup of patients, who may have included those with autoimmune chronic active hepatitis, might also benefit. ${ }^{22}$

With hindsight, the early confusion about the efficacy of immunosuppressive therapy was caused partly by uncertainties about precisely what was the optimal therapeutic dose regimen and partly to aetiological heterogeneity among patients. After the discovery of "Australia antigen', soon to be recognised as a serum marker of hepatitis B virus infection, ${ }^{23}$ it became increasingly apparent that there were at least two aetiological factors involved.

In 1968 Roger Williams took on a post doctoral biochemist, David Haynes, to set up the new serological tests for 'Australia antigen' and delegated the senior medical registrar, Iain MurrayLyon, to undertake what was to be the first published randomised controlled trial of prednisone $v$ azathioprine, demonstrating the efficacy of corticosteroids in improving liver function and prolonging survival. ${ }^{24}$ This was later confirmed by the Mayo Clinic investigators who also demonstrated the now well recognised steroid sparing effect of azathioprine..$^{25}$

During this time, Adrian Eddleston was polishing his immunological expertise in Bob Good's laboratory in Minneapolis (courtesy of an MRC Travelling Fellowship). He had already been over to Copenhagen to learn the intricacies of the leucocyte migration inhibition test from Soberg and Bendixen and had been applying it to the study of autoreactions against liver homogenates with a view to developing a method for assessing rejection in liver transplant recipients. The application of this technique to the study of autoreactions in active chronic hepatitis was a logical extension of this work. Martin Smith (then senior registrar on the Unit) had joined Adrian Eddleston in these endeavours and a second post doctoral biochemist, Joanna Miller (now Joanna King), was taken on. Adrian returned from Minneapolis in 1971 to be greeted with the exciting news from Deborah Doniach of some novel work being undertaken by a German physician, Karl-Herman Meyer zum Buschenfelde.

Meyer zum Buschenfelde had been attempting to develop an animal model of 'autoimmune' hepatitis by injecting rabbits with various fractions of homogenates of normal liver and had found that one particular high molecular weight fraction (LP1), which he had shown to contain a liver specific antigen, seemed to induce a lesion similar to that seen in patients. ${ }^{26}{ }^{27}$ Joanna Miller was quickly despatched to Meyer zum Buschenfelde's laboratory to learn how to prepare LP1, which later became known as the 'liver specific membrane lipoprotein' or 'LSP' - an unfortunate designation which gave rise to much debate and many misconceptions in succeeding years, because it implied that this was a single purified antigenic component. The first paper describing cellular immune responses to liver specific membrane lipoprotein (using the leucocyte migration inhibition test) in patients with active 
chronic hepatitis soon appeared. ${ }^{28}$ Thus began a friendship with Meyer zum Buschenfelde and his group that has lasted more than 20 years and has produced many complementary studies.

In early 1972, Joanna Miller left to get married and Ian McFarlane arrived to continue the work. ${ }^{29}$ The Unit had just moved to new large laboratories above the main liver ward, and the immunology group had grown with the addition of Bill Reed from Australia, and now expanded further with the arrival of Bob Galbraith, Alan Thomson, and Malcolm Cochrane. Alan brought with him expertise in working with isolated hepatocytes which he and Malcolm put to use in the development of in vitro lymphocyte cytotoxicity test systems. These studies led to the first demonstrations that peripheral blood lymphocytes from patients with active chronic hepatitis were able to 'kill' heterologous liver cells in vitro and that these cytotoxic reactions involve a non$T$ cell subset ( $K$ cells) that cooperate with autoantibodies against antigens in the LSP preparation - that is, antibody mediated cellular cytotoxicity (ADCC). ${ }^{30-32}$ The findings were later confirmed in a number of other laboratories around the world, ${ }^{33}{ }^{34}$ but a couple of years were to pass before definitive proof of the existence of anti-LSP antibodies was forthcoming (see below).

In the meantime, Bob Galbraith and Martin Smith had been concentrating on the observation by Mackay and Morris that, in common with other autoallergic conditions, 'autoimmune' active chronic hepatitis is associated with the histocompatibility antigens HLA Al and $B 8 .{ }^{35} \mathrm{~A}$

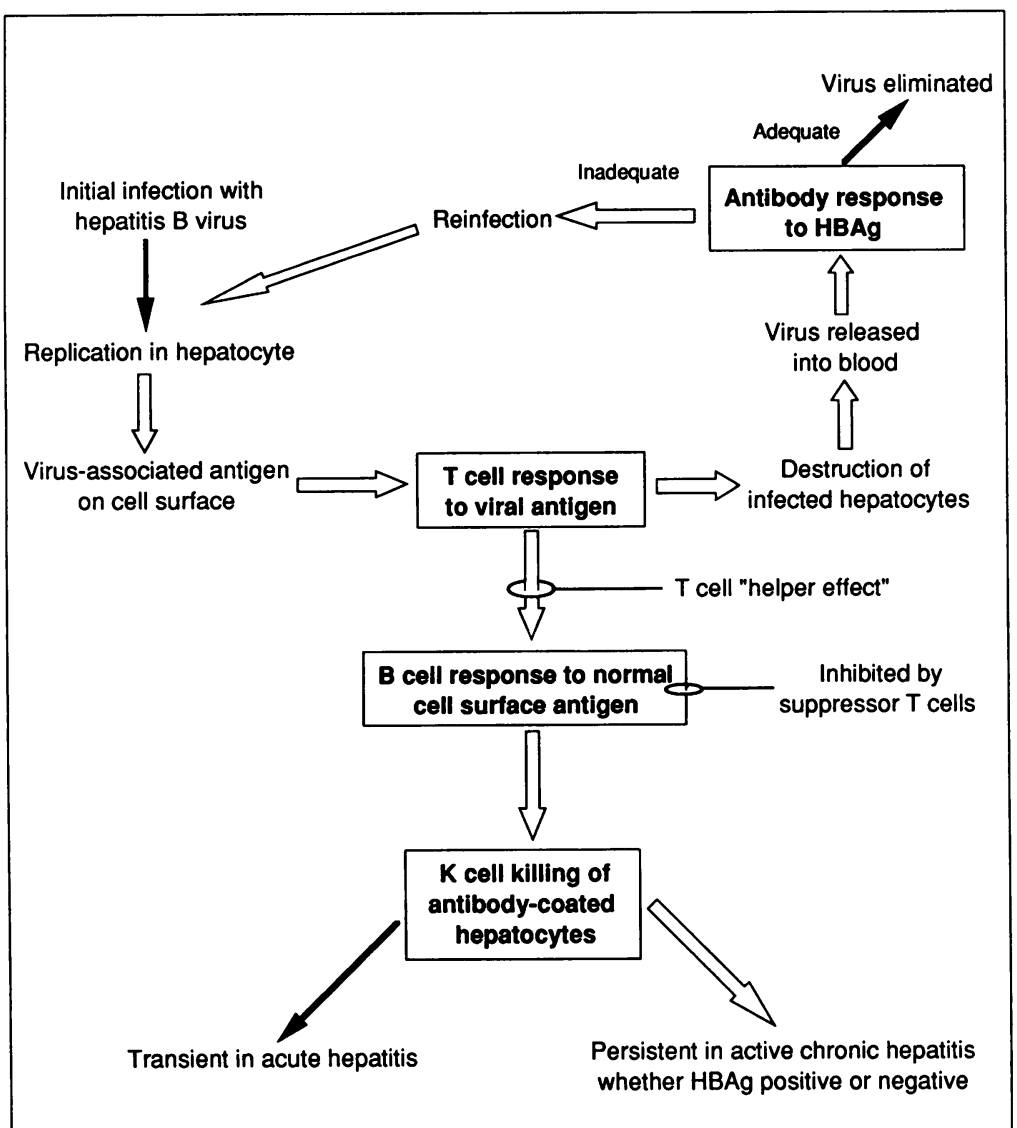

Figure 1: The original Eddleston/Williams hypothesis. collaborative study with Richard Batchelor's group at Guy's Hospital confirmed this finding ${ }^{36}$ and yielded seminal papers on immunogenetic factors predisposing to heightened immune responsiveness in patients with this haplotype. ${ }^{3738}$

On the basis of these early findings Adrian Eddleston and Roger Williams published the first coherent hypothesis ${ }^{39}$ on the pathogenesis of active chronic hepatitis (Fig 1). They proposed that the disease was initiated by the hepatitis B virus. In those who were $\mathrm{HBsAg}$ negative it was postulated that the virus was eliminated normally but, because of a suppressor T cell defect, B cell hyperactivity was not suppressed - leading to persistence of an immune reaction.

At this stage, the question of whether liver specific autoantibodies were involved in the pathogenesis of active chronic hepatitis (suggested by Malcolm Cochrane's finding of antibody immediated cellular cytotoxicity reactions directed at antigens in LSP was still unresolved. Ian McFarlane and Don Jensen, a clinical research fellow from Chicago, turned their attention to this problem. A radioimmunoassay for anti-LSP antibodies was developed ${ }^{40}$ and the first demonstration of anti-LSP in patients' sera reported. ${ }^{41}$ The findings were quickly confirmed by Kakumu in Japan ${ }^{42}$ and by Karl Meyer zum Buschenfelde's group in Germany, ${ }^{43}$ and an Australian post doctoral biochemist, Theonne deKretser, working with Ian McFarlane showed that anti-LSP in patients' sera reacted with an antigen expressed in liver plasma membranes. ${ }^{44}$

Increasing interest in this syndrome, which was becoming more generally known as chronic active hepatitis (CAH), and recognition of its aetiological heterogeneity led to several attempts to define diagnostic criteria. ${ }^{45-47}$ Roger Williams was invited to participate in an international symposium at the Fogarty Centre in Washington that made a major contribution to the debate, ${ }^{46}$ although the designation 'autoimmune' was still not accepted, the term 'HBsAg-negative chronic active hepatitis' being preferred. Gradually, however, the various criteria became established, with recognition that features of $\mathrm{CAH}$ could occur not only in patients with chronic hepatitis $B$ virus infections (HBV-CAH) or those in whom autoimmunity seemed to be the underlying mechanism, but also in cases of primary biliary cirrhosis, $\alpha$-1-antitrypsin deficiency, Wilson's disease, alcoholic liver disease and other conditions, and there was increasing acceptance of the importance of chronic non-A, non-B viral infections. These debates provided the ground rules for stricter classification of chronic active hepatitis and paved the way for the sub-division of CAH into more homogenous groups in which various therapeutic measures could be properly assessed.

During this time, the Liver Unit had entered what became known as its 'Italian period'. Alfredo Alberti, and Diego Vergani and his wife Giorgina (a paediatrician who had come over to join Alex Mowat's childhood liver disease team), and other Italians (up to seven at one time), joined the growing ranks of overseas clinical research fellows. Coming from a country where viral hepatitis is a major problem, it was not 
surprising that their interests focused on the role of the hepatitis B virus in chronic active hepatitis. Work that had begun with Bill Reed and, later, Will Lee from New York, ${ }^{48} 49$ now proceeded apace. The contributions made by this group are reviewed elsewhere in this issue but it is important to mention here the studies by Giorgina and Diego Vergani who have since carved out separate careers respectively in the Departments of Child Health and Immunology at King's.

They adapted Malcolm Cochrane's cytotoxicity test system to the study of cellular immune reactions against patients' own liver cells obtained from liver biopsies and showed for the first time a clear separation in putative mechanistic terms of HBV-CAH from autoimmune $\mathrm{CAH}$, providing further support for 'the hypothesis'. ${ }^{39}$ Thus, whereas non- $T$ cell cytotoxicity (antibody mediated cellular cytotoxicity) against hepatocytes is a feature of both conditions, $T$ cell cytotoxicity was found to be exclusive to HBVCAH. ${ }^{50} 51$ This laid the groundwork for two other Italians, Mario Mondelli and Sandro Vento, and Nikolai Naoumov (from Bulgaria) to dissect further the underlying mechanisms in the two conditions and to identify the viral targets of the $\mathrm{T}$ cell attack in hepatitis $\mathrm{B}$ virus-chronic active hepatitis. ${ }^{52-54}$

In parallel with these studies, Kayhan NouriAria, a doctoral student in immunology, had been investigating the functional defect in nonantigen-specific suppressor $T$ cells in chronic active hepatitis and her findings led to an interesting insight into the mechanism of action of corticosteroids in this condition. She showed that, whereas this defect occurs in both autoimmune and hepatitis B virus-related $\mathrm{CAH}$, only in autoimmune $\mathrm{CAH}$ can it be corrected by corticosteroids. ${ }^{55}$ She further showed that the defect in autoimmune CAH is inherited in linkage with the HLA A1-B8-DR3 haplotype ${ }^{56}$ (Fig 2a) and that it is related to an inability by the patients' $T$ cells to suppress $\mathrm{B}$ cell production of $\mathrm{IgG}^{57}$ (including autoantibodies and antibodies against various pathogens) - thereby explaining the heightened immune responsiveness in these patients noted by Bob Galbraith. ${ }^{37} 38$

Kayhan Nouri-Aria's findings also provided an explanation for the differential modes of action of corticosteroids and azathioprine. To date there have been no reports that $T$ cells directly lyse hepatocytes in autoimmune $\mathrm{CAH}$ and all of the evidence (for review se ${ }^{58}$ ) supports the earlier observations that the liver cell damage is likely to be mediated by a non-T cell (ADCC) mechanism, probably involving autoantibodies against liver cell surface antigens cooperating with $K$ cells. Corticosteroids do not act directly on nonT lymphocytes (including B, K or NK cells), and the finding that pharmacological concentrations of prednisolone can induce $T$ cells to suppress IgG production by $\mathrm{B}$ cells in vitro ${ }^{57}$ is in keeping with the well recognised rapid effect of steroids in vivo. In contrast, azathioprine is known to act on $\mathrm{K}$ and NK cells, but it takes six to 12 months to reduce the numbers of these cells in the circulation to about $5 \%$ of normal ${ }^{5960}$ - suggesting that the drug acts on $\mathrm{K} / \mathrm{NK}$ stem cells in the bone marrow. Thus, in the absence of previous steroid therapy, there are likely to be ample numbers of $\mathrm{K}$ cells circulating that can cooperate with autoantibodies to lyse hepatocytes. The contrasting effects of the two drugs may explain why remission can often be fairly quickly induced by corticosteroids but not azathioprine while, once remission has been achieved, it is possible to maintain patients on azathioprine alone (see below) - since, even if autoantibodies reappear after withdrawal of steroids, there will be insufficient $\mathrm{K}$ cells to cause hepatocellular damage.

These studies had been prompted by John Hegarty's experience in attempting to wean patients with autoimmune CAH off immunosuppressive therapy. After Iain Murray-Lyon's trial of prednisone $v$ azathioprine, ${ }^{24}$ and the later studies from the Copenhagen Study Group and the Mayo Clinic, ${ }^{21} 2561$ standard treatment for autoimmune chronic active hepatitis in the Liver Unit had become: induction of remission with $30-40 \mathrm{mg} /$ day of prednisolone, then introduc-
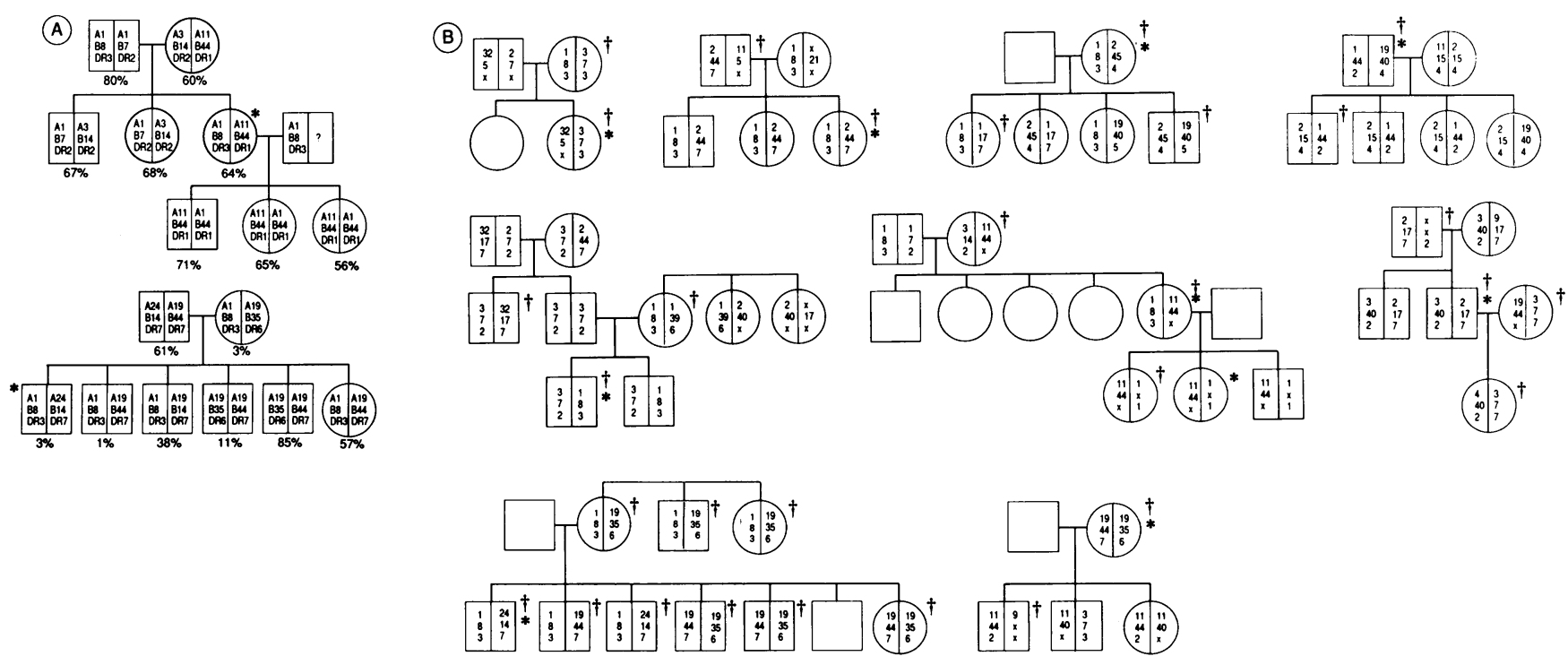

Figure 2: Inherited functional defects in $T$-lymphocyte suppression (T suppression) of immune responses in families of patients ( $\star$ ) with autoimmune chronic active hepatitis. (a) Non-antigen-specific T suppression defect (percent Con-A-induced suppression-normal range 65-95\%) in linkage with HLA A1-B8$D R 3$. (b) Antigen-specific (for asialoglycoprotein receptor) $T$ suppression defect $(\dagger)$ not linked with Al-B8-DR3. $\times$ homozygous or null/untypable allele. 
tion of azathioprine at $1 \mathrm{mg} / \mathrm{kg} /$ day after one to two months and gradual reduction of the steroids over the next six to 12 months to a maintenance regime of $7 \cdot 5-10.0 \mathrm{mg}$ /day of prednisolone with azathioprine. John Hegarty had joined the Unit from Dublin in 1979 to find a large group of patients who had been maintained in complete remission on this regime for a number of years and, concerned about the undesirable side effects of longterm steroid therapy, had discussed with Roger Williams the possibility of attempting to wean them off immunosuppression. Being aware of the likely aetiological heterogeneity within this group, he carefully selected a subgroup of $\mathbf{3 0}$ patients who had fulfilled quite stringent criteria for a diagnosis of 'classical' autoimmune chronic active hepatitis at presentation - that is, symptoms > six months, no demonstrable aetiological factor, compatible histology, raised serum IgG,

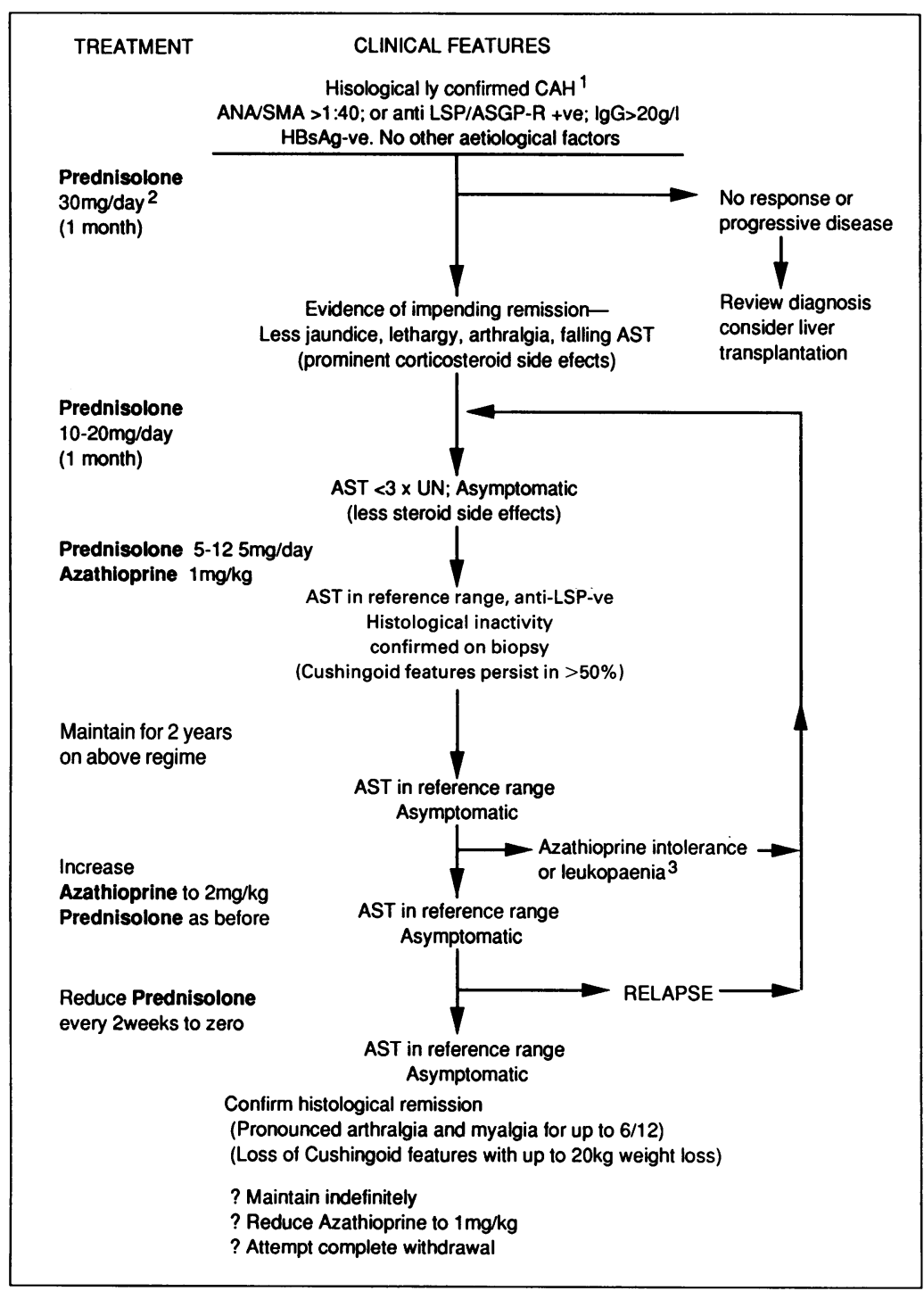

Figure 3: Current Liver Unit management of patients with autoimmune chronic active hepatitis. ${ }^{1}$ Histological confirmation of the diagnosis may have to await normalisation of the prothrombin time or be obtained by the transjugular approach. ${ }^{2}$ Doses of prednisolone of greater than $30 \mathrm{mg} /$ day are seldom, if ever, indicated in autoimmune-chronic active hepatitis. Some $e^{117}$ would reserve treatment for those with bridging necrosis and symptoms ${ }^{117}{ }^{3}$ Many patients are leucopenic before azathioprine therapy because of hypersplenism; it is a falling white cell or platelet count rather than an absolute leucopenia (or thrombocytopaenia) that is the indication for reduction or withdrawal of the drug. ${ }^{4}$ Relapse is arbitrarily defined as an $A S T>3 \times$ upper limit of normal $(U L N)$. Relapse is unusual at other stages in management but always requires reintroduction of corticosteroids. When relapse is detected presymptomatically (by AST elevation), remission can usually be re-induced with less than $30 \mathrm{mg} /$ day of prednisolone. and antinuclear (ANA) and/or anti-smooth muscle (SMA) antibodies at titres of 1:40 or greater. Azathioprine was discontinued and the steroid dose reduced by $2 \mathrm{mg} /$ day at fortnightly intervals. Twenty six $(87 \%)$ of the patients relapsed within one year of starting the trial (21 within nine weeks - 15 before prednisolone was completely withdrawn). ${ }^{62}$

A second trial, attempting to prevent this high relapse rate by administering a thymic hormone extract (which had been shown to stimulate suppressor $\mathrm{T}$ cell activity and inhibit immunoglobulin production in vitro) at the start of steroid dose reduction, was equally unsuccessful. ${ }^{63}$

In both studies, however, John Hegarty had been struck by the fact that so many patients seemed to relapse even before steroids had been completely withdrawn, and he wondered whether this might have been due to stopping the azathioprine. Tony Stellon was set to tackle this question. The resulting controlled trial showed that, indeed, relapse frequently followed withdrawal of azathioprine as the only change in therapy $-32 \%$ relapsing within 18 months $v$ only $6 \%$ of those maintained on combination therapy. ${ }^{64}$

The problem of how to wean patients off steroids remained but, at this point, John Hegarty showed the value of occasionally rereading the early literature. He noted that, in 1968, Ian Mackay had shown that a small number of patients could be maintained on azathioprine alone $e^{65}$-albeit at somewhat higher doses $(1.5-2.5 \mathrm{mg} / \mathrm{kg} /$ day $)$ than in the standard regime above. A fourth trial was therefore instituted, in which patients in remission on the combination therapy had their azathioprine increased to $2 \mathrm{mg} / \mathrm{kg} /$ day before gradually withdrawing the prednisolone. Despite an unexplained syndrome of arthralgia and myalgia which afflicted many patients for up to one year after steroid withdrawal, this proved highly successful ${ }^{66}$ and forms the basis of our current management plan (Fig 3). At the time of writing, 95 of our patients are being maintained on this regime and 77 have sustained remission for up to six years. Of the remaining 18 , reinstitution of prednisolone was required because of relapse in eight and because of myelosuppression in 10. A controlled trial is currently underway to determine whether, after a time, the azathioprine dosage can be reduced again to $1 \mathrm{mg} / \mathrm{kg} /$ day with continued maintenance of remission.

The sera collected by John Hegarty in the first steroid withdrawal trial proved invaluable. Although the early studies of anti-LSP had shown that titres of these autoantibodies correlated very well with histologically assessed severity of disease, ${ }^{41}$ independently of biochemical correlates, their value for routine monitoring of disease activity during therapy had not been investigated. Retrospective analysis of the sera from that trial showed that rising titres of antiLSP (as early as three months before the first rises in aminotransferase) almost invariably predicted the relapses. ${ }^{67}$ As a result of this finding, anti-LSP was added to the laboratory tests used in the Liver Unit for routine monitoring of the patients.

Inevitably, the clinical trials concentrated on 


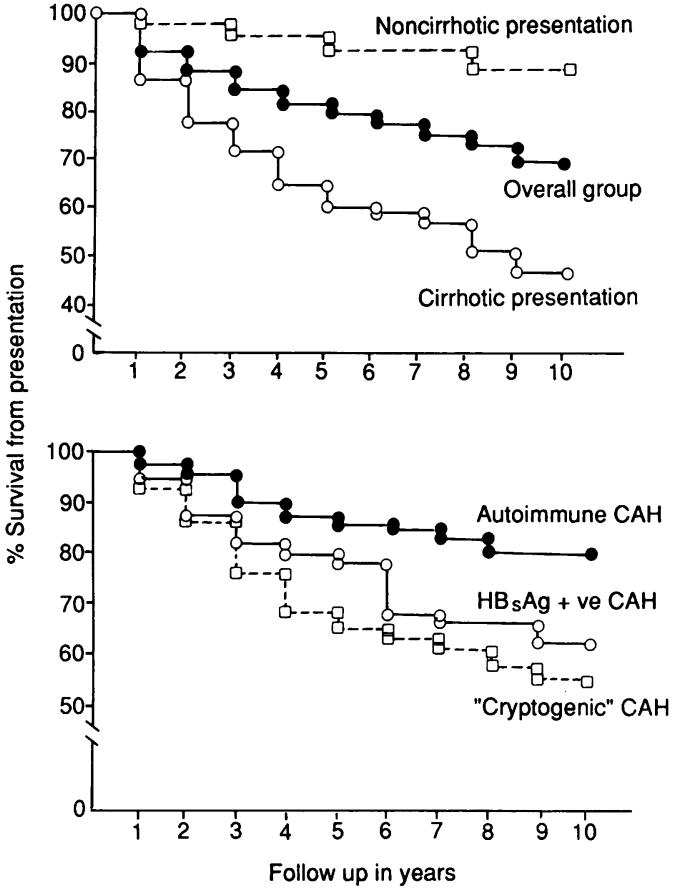

Figure 4: Survival of patients with chronic active hepatitis in relation to (a) presence or absence of cirrhosis at presentation and $(b)$ aetiology. The poor survival of those with

'cryptogenic' disease is accounted for by their high frequency of cirrhosis.

relatively short term end points. In a disease which frequently affects young people, however, assessment of the longterm prognosis is of considerable importance, particularly to young women contemplating a family. By 1985 the Unit had follow up on a large group of patients spanning more than 15 years and these data were reviewed in 1987 by John Keating. ${ }^{68}$ The analysis involved 102 patients with 'classical autoimmune' and 68 with 'cryptogenic' chronic active hepatitis - that is, those with neither conventional autoimmune markers nor any other identifiable aetiological factor. Using multivariate analysis it became clear that the major independent factor influencing survival was the presence of cirrhosis at presentation - irrespective of whether the chronic active hepatitis was cryptogenic, autoimmune or hepatitis B virusrelated. In the presence of cirrhosis, the 10 year year survival was $48 \%$ compared with $90 \%$ when cirrhosis was absent (Fig 4). This study also showed that despite effective treatment the major causes of death were still related to hepatic failure. As noted in several early studies ${ }^{524}$ hepatocellular carcinoma occurred occasionally in all types of chronic active hepatitis, including the autoimmune type, an observation subsequently described in more detail by the Mayo Clinic group. ${ }^{69}$

The optimal management of patients with cryptogenic $\mathrm{CAH}$ - as defined above - remains controversial. There has been an increasing tendency to consider that, by elimination, these patients have some form of non-A, non-B hepatitis and that corticosteroid therapy is, therefore, inappropriate. Review of those attending our clinic revealed 12 patients who, despite the absence of conventional autoantibodies - that is, SMA or ANA, all had a complete remission induced by immunosuppressive agents both ini- tially and after subsequent relapses during attempts at treatment withdrawal. The clue to the autoimmune nature of their disease, and the potential for successful immunosuppressive therapy, came from the high titres of anti-LSP or anti-ASGP-R antibodies (see below) which were detected in all. ${ }^{70}$ Until reliable tests for the non$A$, non- $B$ viruses become available our policy is to undertake a trial of immunosuppressive therapy in patients with cryptogenic CAH who have either anti-LSP or anti-ASGP-R antibodies.

In the meantime, work on the identification of antigenic targets in liver specific membrane lipoprotein had been continuing. Ian and Barbara McFarlane showed that LSP contains the galactose-specific hepatic asialoglycoprotein receptor(ASGP-R) ) $^{71}$ which, being normally expressed on hepatocyte surfaces, ${ }^{73}$ seemed a likely candidate target for tissue-damaging autoreactions. They went on to establish that patients with chronic active hepatitis have circulating autoantibodies against this receptor at titres that correlate closely with histological severity of the disease $^{74}$ - a finding that has been recently confirmed by Meyer zum Buschenfelde's group in Germany. ${ }^{75}$ In contrast to anti-LSP, antiASGP-R is found infrequently in most other liver disorders and is particularly rare in acute or chronic non-A, non-B infections. ${ }^{74-77}$ Thus, antiASGP-R testing was added to the repertoire of routine tests, particularly for the differential diagnosis of autoimmune $\mathrm{CAH}$ from chronic non-A, non-B infection.

Developments were also taking place in the field of cellular autoreactions in autoimmune chronic active hepatitis. Sandro Vento and Charles O'Brien (who had joined the Unit from Belfast) had been examining the ability of patients' $T$ lymphocytes to recognise antigens in LSP. They found that $T$ cells from autoimmune CAH (but not HBV-CAH) patients are 'sensitised' to LSP and that this immune response is directed at the asialoglycoprotein receptor, and is both antigen-specific and disease-specific. ${ }^{789}$ Furthermore, they showed that it can be 'switched off' in vitro by coculturing the patients' cells with small numbers $(10 \%)$ of lymphocytes from normal subjects or patients with other liver or autoimmune disorders, but not with cells from other autoimmune CAH patients. ${ }^{78-81}$ These findings indicated that normal subjects (and other individuals without autoimmune $\mathrm{CAH}$ ) have circulating activated $T$ cells that recognise and suppress the immune response to the asialoglycoprotein receptor, while patients with autoimmune $\mathrm{CAH}$ have a functional defect in this $\mathrm{T}$ suppression mechanism. ${ }^{81}$ They also showed that this $T$ suppression defect resides in a sub-population of suppressor-inducer $(\mathrm{CD} 4+) \mathrm{T}$ cells and is inherited in an autosomal, non-HLAlinked mode ${ }^{80} 81$ (Fig 2b).

Putting all of the data together, important mechanistic distinctions between autoimmune and HBV-related CAH began to appear (Table). Thus, both conditions are associated with: (a) anti-ASGP-R antibodies, (b) ADCC reactions probably involving anti-ASGP-R, and (c) in common with non-hepatic autoimmune disorders, a non-antigen-specific suppressor $\mathrm{T}$ cell defect. In autoimmune CAH however (but not 
TABLE Summary of evidence relating to humoral and cellular liver autoreactions in autoimmune (autoimmune-chronic active hepatitis) and hepatitis $B$ virus related (hepatitis $B$ virus-chronic active hepatitis) chronic active hepatitis

\begin{tabular}{|c|c|c|}
\hline Parameter & $A I-C A H$ & $H B V-C A H$ \\
\hline T-cell cytotoxicity $v$ autologous hepatocytes & No & Yes \\
\hline $\begin{array}{l}\text { Non-T-cell cytotoxicity } v \text { autologous and heterologous hepatocytes } \\
\text { antibody immediated cellular cytotoxicity }\end{array}$ & Yes & Yes \\
\hline T-cells 'sensitised' to: & & \\
\hline (a) liver specific membrane lipoprotein & Yes & No \\
\hline (b) asialoglycoprotein receptor & Yes & No \\
\hline Non-antigen-specific suppressor T cell defect & Yes & Yes \\
\hline $\begin{array}{l}\text { Antigen-specific T suppression defect in control of autoreactivity to } \\
\text { asialoglycoprotein receptor }\end{array}$ & Yes & No \\
\hline Anti-liver specific membrane lipoprotein antibodies & Yes & Yes \\
\hline Anti-asialoglycoprotein receptor antibodies & Yes & Yes \\
\hline
\end{tabular}

HBV-CAH): (a) the non-antigen-specific T suppression defect is inherited in linkage with HLA A1-B8-DR3 and is corrected by steroid therapy, (b) there is an additional, hereditary, antigenspecific (for ASGP-R) T suppression defect that is unique to the disease, is not HLA-linked and is not correctable by corticosteroids. From this it seems likely that, in autoimmune chronic active hepatitis, immunogenetic factors are involved while, in HBV-CAH, the autoreactivity is virusdriven - probably through hepatitis $B$ virusinduced polyclonal activation of autoreactive $B$ cells, leading to production of anti-ASGP-R antibodies.

In the past, very little attention has been devoted to the question of why liver damage in chronic active hepatitis is primarily confined to the periportal areas of the liver lobule. Although $T$ cell cytotoxicity against viral antigens expressed on the surfaces of hepatocytes in HBV$\mathrm{CAH}$ is likely to be involved, it is difficult to see how this can explain the pattern of liver damage because virus-infected cells are not particularly concentrated in the periportal areas. ${ }^{82}$ Barbara McFarlane decided to explore the hypothesis that, given that anti-ASGP-R antibodies and ADCC reactions are demonstrable in both autoimmune and $\mathrm{HBV}-\mathrm{CAH}$, perhaps high concentrations of anti-ASGP-R antibodies entering the liver might preferentially coat periportal hepatocytes, rendering them more susceptible to damage by antibody imediated cellular cytotoxicity

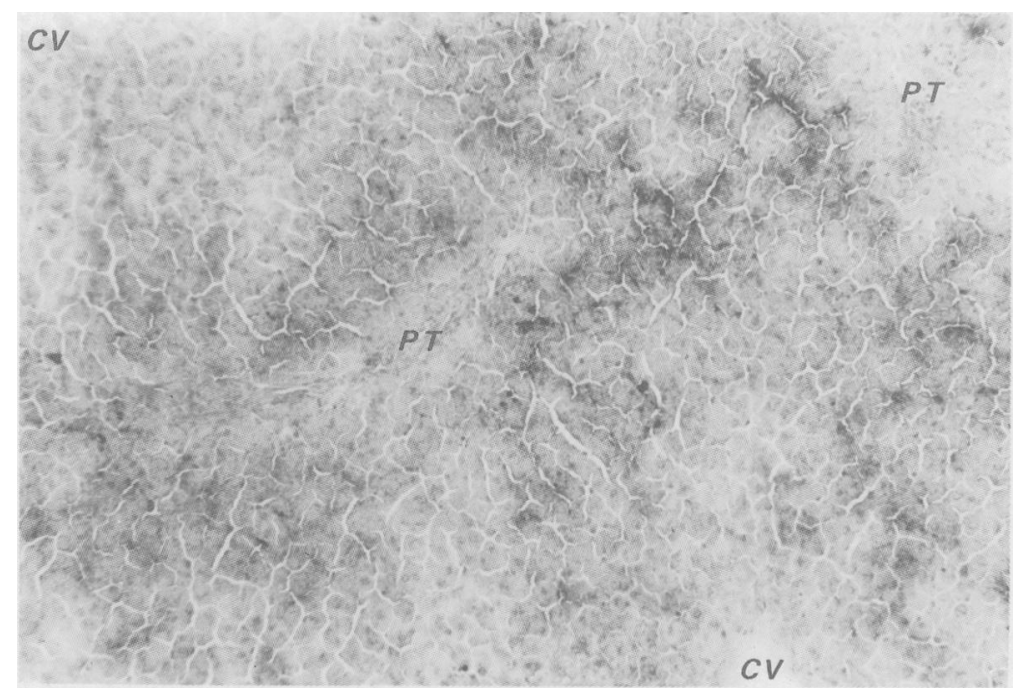

Figure 5: Immunohistochemical localisation of anti-asialoglycoprotein receptor antibodies in rat liver following in situ perfusion with guinea-pig anti-asialoglycoprotein receptor in a retrograde direction. $P T=$ portal tracts. $C V=$ central veins. reactions. She perfused animal polyclonal and monoclonal anti-ASGP-R antibodies through rat livers and then used a sensitive immunohistochemical technique to locate the antibodies in sections of the snap frozen livers. She found that the anti-ASGP-R antibodies did indeed preferentially bind to periportal hepatocytes but, surprisingly, this was not due to a concentration gradient effect because perfusion in the retrograde direction (via the hepatic veins) yielded identical results ${ }^{83}$ (Fig 5). Rather, the findings indicated that the target of these antibodies, the asialoglycoprotein receptor, is preferentially and almost exclusively expressed on the surfaces of periportal hepatocytes - a conclusion supported by ligand binding studies by Daniels in California. ${ }^{84}$

To explain the fact that, although autoimmune chronic active hepatitis may occasionally develop in children, the majority of patients present later in life, it has been assumed that some environmental and/or hormonal factor must be involved in triggering the disease in susceptible subjects. Hepatotropic viruses are obviously prime candidates as putative triggers of this condition and several have now been implicated, albeit largely circumstantially (for review see ${ }^{85}$ ). Whilst non-A, non-B hepatitis has been recognised for many years as a cause of chronic active hepatitis ${ }^{86}$ there was little reason to implicate such viruses in the pathogenesis of the autoimmune type.

Furthermore, although piecemeal necrosis is seen during the acute phase in non- $A$, non-B infections, ${ }^{8788}$ the histologic picture in chronic non-A, non-B hepatitis is more that of a chronic lobular hepatitis with biliary lesions than of classical chronic active hepatitis. ${ }^{89}$ In addition, there are changes (cytoplasmic eosinophilia, granularity and distortion, acidophilic bodies) suggestive of cytopathic virus infection, ${ }^{89} 90$ and two separate studies ${ }^{9192}$ have shown that there is a predominantly $\mathrm{T}$ cell cytotoxic immune response against autologous hepatocytes in acute and/or chronic non- $A$, non-B hepatitis, with minimal or no non-T cell killing (in contrast with $\mathrm{HBV}$ $\mathrm{CAH}$, see above), suggesting that host immune responses against virus-infected cells are the major cause of the liver damage. In addition, apart from one report of liver membrane antibodies occurring in a high proportion of patients, ${ }^{93}$ liver autoreactivity has not been considered a significant feature of acute or chronic non-A, non-B hepatitis. Indeed, non-organspecific $^{7476}$ and other autoantibodies including anti-LSP and anti-ASGP-R (see above) are found infrequently in non-A, non-B infections - to the extent that their absence has been widely used as one of the criteria for differentiating chronic non$A$, non-B infection from autoimmune $\mathrm{CAH}$.

The findings of a high frequency of antibodies to the hepatitis $\mathrm{C}$ virus (HCV) in two recent studies, one from Spain ${ }^{94}$ involving patients with type- 1 autoimmune-CAH (ANA/SMA positive), and the other from Italy, ${ }^{95}$ involving type- 2 patients ( $\mathrm{LKM}_{1}$ positive) therefore came as a surprise. In a selected group of our type-1 patients who fulfilled strict criteria for a diagnosis of autoimmune CAH and, in particular, had no history of exposure to hepatotropic viral infections, we too found a high frequency (45\% 
overall) of positive results using the Ortho $\mathrm{HCV}$ ELISA, the same assay as used in the Spanish and Italian studies referred to above. The optical density values in the ELISA, however, correlated very closely with serum globulin and IgG concentrations in the patients' sera which, we suggested, might indicate false-positive results. ${ }^{96}$ Several studies have now confirmed that the original immunoassays for anti-HCV antibodies are prone to false positivity ${ }^{97-101}$ - including one attributing false positives in autoimmune $\mathrm{CAH}$ patients to circulating antibodies against superoxide dismutase, which is part of the $\mathrm{HCV}$ (C$100-3$ ) fusion protein used as the antigen in the assay. ${ }^{98}$

Such a correlation between optical density and globulin concentrations, however, was not seen among the Italian patients and it occurred to us that there might be fundamental differences between populations of patients in different countries with respect to frequency of hepatitis $C$ virus exposure. Accordingly, we undertook a collaborative study with the Italian group ${ }^{118}$ using a new ELISA (United Biomedical Inc (UBI), based entirely on synthetic HCV peptides, which seemed not to have the problems of nonspecificity inherent in the recombinant peptidebased assays. The results showed very clearly that whilst in United Kingdom born patients the UBI assay was almost always negative, about $50 \%$ of Italian patients with type-1 disease and more than $80 \%$ with type- 2 disease were indeed very strongly positive.

The interpretation of these data is, at the time of writing, unclear. Because autoimmune chronic active hepatitis patients have high titres of antibodies against the measles and rubella viruses and other pathogens ${ }^{37} 38$ it is likely that, in areas (such as the Mediterranean) where there is a high frequency of non- $A$, non-B hepatitis, a proportion of such patients may have persisting anti-HCV after an earlier (undocumented) exposure to the virus without necessarily having chronic $\mathrm{HCV}$ infection or presuming that $\mathrm{HCV}$ induced their autoimmune chronic active hepatitis.

Alternatively, these may represent unique groups of patients in whom hepatitis $\mathrm{C}$ virus induces autoantibody responses - possibly reflecting genetic differences between populations.

The Unit's efforts at elucidating the mechanisms underlying the development of autoimmune CAH over the years have concentrated on studies in patients, in part because early attempts by others to reproduce Karl Meyer zum Buschenfelde's model of chronic active hepatitis ${ }^{27}$ in rabbits or mice had met with variable success. ${ }^{102-105}$ Bill Reed had, however, maintained his interest in liver specific membrane lipoprotein after his return to Australia. In a series of elegant studies, he and his colleagues showed that mice immunised with LSP would produce autoantibodies against antigens in this preparation but that the response was strain-dependent (implying the involvement of immunogenetic factors). They went on to show that murine cytomegalovirus infection induces an anti-LSP response in mice, analogous to the response in patients with acute hepatitis $A$ or $B,{ }^{106}$ and that this virus-induced autoimmune response is dependent on autoantigen recognition by $T$ lymphocytes which then induce B cells to produce the autoantibodies. ${ }^{107}$ The latter observation is more in keeping with the findings in patients with acute hepatitis $A$ or $B^{108}$ than those in HBV-CAH patients, who do not seem to show $T$ cell responses to LSP or the asialoglycoprotein receptor (see above).

In those studies the mice did not develop lesions similar to chronic active hepatitis, but a possible explanation for this (and for the variable results of others who had attempted to develop animal models of $\mathrm{CAH}$ ) came later from Mori and colleagues in Japan. ${ }^{105}{ }^{109}$ The latter group not only confirmed that the autoreactive response is strain dependent but also showed that it is partly inhibited by EDTA, which is routinely used to stabilise LSP preparations. ${ }^{29}$ They further showed that CAH-like lesions induced by immunising mice with EDTA-free liver extracts could be adoptively transferred to unimmunised mice, particularly if suppressor $T$ cell function was first abrogated by low dose irradiation in the donor animals. ${ }^{110-112}$ These findings have now been confirmed in part by Meyer zum Buschenfelde's group in Germany. ${ }^{113}$

One question that has bedevilled the above studies demonstrating cellular immune reactions involving peripheral blood lymphocytes in vitro is whether these have any real relevance to possible autoreactions at the sites of tissue injury in the liver. Collaborative studies with the Departments of Child Health and Immunology at King's have, however, now shown that clonally expanded peripheral blood T-cells specifically recognise liver antigens (including the asialoglycoprotein receptor) and stimulate autologous B lymphocytes to produce liver membrane specific autoantibodies, including anti-ASGP-R. ${ }^{114}$ Meyer zum Buschenfelde's group in Germany has independently obtained similar results and, additionally, has shown that ASGP-R autoreactive $T$ cell clones can be derived from lymphocytes isolated from patients' liver biopsies. ${ }^{115}$

\section{Future challenges}

A major disappointment must be that despite more than a quarter of a century's intensive study, there are still no real, internationally agreed, criteria for the diagnosis of 'autoimmune' chronic active hepatitis or guidelines on what constitutes 'relapse' or 'remission'; without these, comparison of results from different centres remains difficult. Furthermore, despite the carefully controlled trials of immunosuppressive therapy, the applicability of the early studies to patients seen today, with disease which is often mild or detected asymptomatically, are not certain. Concern has been expressed that the evidence supporting corticosteroid treatment of this group, particularly when bridging necrosis is absent, is weak. ${ }^{116}$ The longterm safety of high dose azathioprine also needs to be carefully monitored.

Because we see relatively few patients with LKM $M_{1}$ antibodies (type 2 autoimmune-CAH), the present review has tended to concentrate on 
type 1 disease. The question of whether these do really represent two separate disease entities remains open. In addition to the apparent association of hepatitis $C$ virus infection with type 2 autoimmune-CAH, however, there has been some exciting new work on the identification of the target antigens of LKM antibodies - not least of which is a recent preliminary report from Michael Manns of molecular mimicry between a hexapeptide segment of the intermediate early protein (IE175) of herpes simplex virus and an octapeptide representing the smallest immunogenic fragment of the $\mathrm{LKM}_{1}$ target antigen, cytochrome P450 IID6. ${ }^{117}$

Other important and unresolved questions remain: does immunosuppressive therapy influence the development of fibrosis and, ultimately, cirrhosis? How should we manage patients presenting with, if we can allow the contradiction in terms, acute disease? Specifically, should that group who present with a small liver and signs of liver failure (ascites and/or hepatic encephalopathy) receive corticosteroid therapy, or be considered immediately for liver transplantation? How should autoimmune-CAH which does not respond to corticosteroids be managed? Cyclosporin A has been disappointing but rapid progression to liver failure is by no means inevitable. The elucidation of the role of hepatitis $C$ and other viruses in the immunopathogenesis of autoimmune-chronic active hepatitis is still in its infancy.

It is, however, a fitting conclusion to this review that, after 20 years of clinical trials (and tribulations!), the majority of our patients are now so firmly established on a regimen (azathioprine maintenance) which is effective and free of side effects, that they decline to enter any further study. With the help of the patients' local consultants, the clinic still serves nearly 150 patients with autoimmune $\mathrm{CAH}$, many of whom travel long distances to attend. The collaboration between research centre, local hospital and patient has benefitted all over this last quarter of a century; let us hope that nothing happens in the future to change this productive state of affairs.

1 Waldenstrom J. Leber, Blutproteine und Nahrungseiweiss. Dtsch Gesellschaft Z Verdau Stoffwechselkr 1950; 15: 113-9.

2 Cullinan ER. Idiopathic Jaundice (often recurrent) associated with subacute necrosis of the liver. St Barth Hosp Rep 1936; 69: 55-142.

3 Amberg S. Hyperproteinaemia associated with severe liver damage. Proc Staff Meet Mayo Clin 1942; 17: 360-2.

4 Wilcox RG, Isselbacher KJ. Chronic liver disease in young people. Clinical features and course of thirty-three patients. Am F Med 1961; 30: 185-95.

5 Mistilis SP, Skyring AP, Blackburn CRB. Natural history of active chronic hepatitis. Aust Ann Med 1968; 17: 214-23.

6 Soloway RD, Summerskill WHJ, Baggenstoss AH, et al. Clinical, biochemical, and histological remission of severe chronic active liver disease: a controlled study of treatments and early prognosis. Gastroenterology 1972; 63: 820-33.

7 Joske RA, King WE. The 'L.E.-cell' phenomenon in active chronic viral hepatitis. Lancet 1955; ii: 477-9.

8 Mackay JR, Taft LI, Cowling DC. Lupoid hepatitis. Lancet 1956; ii: 1323-26.

9 Bartholomew LG, Hagedorn AB, Cain JC, Baggenstoss AH. Hepatitis and cirrhosis in women with positive clot tests for lupus erythematosus. $N$ Engl f Med 1958; 259: 947-56.

10 Aronson AR, Montgomery MM. Chronic liver disease with a 'lupus erythematosus-like syndrome'. Arch Intern Med 1959; 104: 544-52.

11 Mackay IR, Taft LI, Cowling DC. Lupoid hepatitis and the hepatic lesions of systemic lupus erythematosus. Lancet 1959; i: 65-9.

12 Bartholomew LG, Cain JC, Baggenstoss AH, Hagedorn AB Further observations on hepatitis in young women with positive clot tests for lupus erythematosus. Gastroenterology 1960; 39: 730-6.
13 Mackay IR, Wood IJ. Lupoid hepatitis: a comparison of 22 cases with other types of liver disease. $Q \mathcal{F}$ Med 1962; 31 : 485-507.

14 Whittingham S, Mackay IR, Irwin J. Autoimmune hepatitis: immunofluorescence reactions with cytoplasm of smooth muscle and glomerular cells. Lancet 1966; i: 1333-5.

15 Whittingham S, Irwin J, Mackay IR, Smalley M. Smooth muscle autoantibody in 'autoimmune' hepatitis. Gastroenterology 1966; 51: 499-505.

16 Doniach D, Roitt IM, Walker JG, Sherlock S. Tissue antibodies in primary biliary cirrhosis, active chronic (lupoid) hepatitis, cryptogenic cirrhosis and other liver diseases and their clinical implications. Clin Exp Immunol 1966; 1: 237-62.

17 Page AR, Condie RM, Good RA. Suppression of plasma cell hepatitis with 6-mercaptopurine. Am F Med 1964; 36: 20013.

18 Mackay IR, Wood IJ. The course and treatment of lupoid hepatitis. Gastroenterology 1963; 45: 4-8.

19 Soloway RD, Summerskill WHJ, Baggenstoss AH, et al. Clinical, biochemical, and histological remission of severe chronic active liver disease: a controlled study of treatments chronic active liver disease: a controlled study of treatme

20 Copenhagen Study Group for liver diseases. Effect of prednisone on the survival of patients with cirrhosis of the liver. Lancet 1969; i: 119-21.

21 Copenhagen Study Group for liver diseases. Sex, ascites, and alcoholism in survival of patients with cirrhosis. Effect of prednisone. N EnglF Med 1974; 291: 271-3.

22 Cook GC, Mulligan R, Sherlock S. Controlled prospective trial of corticosteroid therapy in chronic active hepatitis. QF Med 1971; 158: 159-85.

23 Blumberg BS, Alter HJ, Visnich S. A 'new' antigen in leukaemia sera. $₹ A M A$ 1965; 191 : $541-6$.

24 Murray-Lyon IM, Stern RB, Williams R. Controlled trial of prednisone and azathioprine in active chronic hepatitis. prednisone and azath
Lancet 1973; i: 735-7.

25 Summerskill WHJ, Korman MG, Ammon HV, Baggenstoss AH. Prednisone for chronic liver disease: dose titration, standard dose, and combination with azathioprine. Gut 1975; 16: 876-83.

26 Meyer zum Buschenfelde KH, Miescher PA. Liver specific antigens, purification and characterization. Clin Exp Immunol 1972; 10: 89-102.

27 Meyer zum Buschenfelde KH, Kossling FK, Miescher PA. Experimental chronic active hepatitis in rabbits following immunization with human liver proteins. Clin $\operatorname{Exp} \operatorname{Immu-}$ nol 1972; 11: 99-108.

28 Miller J, Smith MGM, Mitchell CG, Reed WD, Eddleston ALWF, Williams R. Cell-mediated immunity to human liver-specific antigen in patients with active chronic hepativer-specific antigen in patients with active chronic hepa-

29 McFarlane IG, Wojcicka BM, Zucker GM, Eddleston ALWF, Williams R. Purification and characterisation of human liver-specific membrane lipoprotein (LSP). Clin Exp Immunol 1977; 27: 381-90.

30 Thomson AD, Cochrane AMG, McFarlane IG, Eddlesto ALWF, Williams R. Lymphocyte cytotoxicity to isolated hepatocytes in chronic active hepatitis. Nature (London) 1974; 252: 721-2.

31 Cochrane AMG, Moussouros A, Thomson AD, Eddleston ALWF, Williams R. Antibody-dependent cell-mediated ( $\mathrm{K}$ cell) cytotoxicity against isolated hepatocytes in chronic active hepatitis. Lancet 1976; i: 441-4.

32 Gonzales C, Cochrane AMG, Eddleston ALWF, Williams R Mechanisms responsible for antibody-dependent, cellmediated cytotoxicity to isolated hepatocytes in chronic active hepatitis. Gut 1979; 20: 385-8.

33 Fernandez-Cruse E, Escartin P, Bootello A, Kreisler M, Segovire de Avana JM. Hepatocyte damage induced by lymphocytes from patients with chronic liver disease, as detected by LDH release. Clin Exp Immunol 1978; 31 : 436 42.

34 Vogten AJM, Hadzic N, Shorter RG, Summerskill WHJ, Taylor NF. Cell-mediated cytotoxicity in chronic active liver disease: a new test system. Gastroenterology 1978; 74 883-9.

35 Mackay IR, Morris PJ. Association of autoimmune active chronic hepatitis with HL-A1, 8. Lancet 1972; ii: 793-5.

36 Galbraith RM, Eddleston ALWF, Smith MGM, et al. Histocompatibility antigens in active chronic hepatitis and primary biliary cirrhosis. $B M \mathcal{F} 1975 ; 4: 77-9$.

37 Galbraith RM, Smith M, MacKenzie RM, Tee DE, Doniach $D$, Williams $R$. High prevalence of seroimmunologic abnormalities in relatives of patients with chronic active hepatitis or primary biliary cirrhosis. $N$ Engl F Med 1974; 290: 63-9.

38 Galbraith RM, Eddleston ALWF, Williams R, et al. Enhanced antibody responses in active chronic hepatitis: relation to HLA-B8 and HLA-B12 and portosystemic shunting. Lancet 1976; i: 930-4.

39 Eddleston ALWF, Williams $\mathrm{R}$. Inadequate antibody response to $\mathrm{HBAg}$ or suppressor T-cell defect in develop-

Jensen DM, McFarlane IG, Nicholson A, Eddleston ALWF Williams R. The development of a radioimmunoassay for the detection of antibodies to a liver-specific membrane the detection of antibodies to a liver-specific memb.
lipoprotein (LSP). F Clin Lab Immunol 1978; 1: 31-5.

41 Jensen DM, McFarlane IG, Portmann BS, Eddleston ALWF, Williams R. Detection of antibodies directed against liver-specific membrane lipoprotein in patients with acute and chronic active hepatitis. N Englf Med 1978; 229: $1-7$

42 Kakumu S, Arakawa Y, Goji H, Kashio T, Yata K. Occurrence and significance of antibody to liver-specific 
membrane lipoprotein by double-antibody immunoprecipitation method in sera of patients with acute and chronic liver disease. Gastroenterology 1979; 76: 665-72.

43 Manns M, Meyer zum Buschenfelde KH, Hess G. Autoantibodies against liver-specific membrane lipoprotein in acute and chronic liver diseases: studies on organ-. speciesand disease-specificity. Gut 1980; 21: 955-61.

44 DeKretser TA, McFarlane IG, Eddleston ALWF, Williams R. A species non-specific liver plasma membrane antigen and its involvement in chronic active hepatitis. Biochem $\mathcal{F}$ 1980; 186: 679-85.

45 Popper H, Schaffner F. Chronic hepatitis: taxonomic, etiologic and therapeutic problems. In: Popper H, Schaffner F, eds. Progress in liver disease. Vol V. New York: Ann NY Acad Sci, 1976: 531-8.

46 Standardization of nomenclature, diagnostic criteria and diagnostic methodology. In: Fogarty International Center Proceedings No. 22. DHEW Publ No (NIH) 76-725. Disease of the liver and biliary tract. Washington: US Govt Printing Office, 1976: 9-11.

47 Review by an International Group. Acute and chronic hepatitis revisited. Lancet 1977; ii: 914-9.

48 Reed WD, Zuckerman AJ, Bowes A, et al. Detection of hepatitis B antigen by radioimmunoassay in chronic liver disease and hepato-cellular carcinoma in Great Britain. Lancet 1973; ii: 690-4.

49 Lee WM, Reed WD, Mitchell CG, et al. Cellular and humoral immunity to hepatitis B surface antigen in active chronic hepatitis. BMF 1975; 1: 705-8.

50 Mieli-Vergani G, Vergani D, Jenkins PJ, et al. Lymphocyte cytotoxicity to autologous hepatocytes in $\mathrm{HBsAg}$-negative chronic active hepatitis. Clin Exp Immunol 1979; 38: 16-21.

51 Mieli-Vergani G, Vergani D, Portmann B, et al. Lymphocyte cytotoxicity to autologous hepatocytes in $\mathrm{HBsAg}$-positive chronic liver disease. Gut 1982; 23: 1029-36.

52 Mondelli M, Mieli-Vergani G, Alberti A, et al. Specificity of $T$ lymphocyte cytotoxicity to autologous hepatocytes in chronic hepatitis $B$ virus infection: evidence that $T$ cells are directed against HBV core antigen expressed on hepatocytes. F Immunol 1982; 129: 2773-8.

53 Naoumov NV, Mondelli M, Alexander GJM, Eddleston ALWF, Williams R. Relationship between expression of HBV antigens in isolated hepatocytes and autologous $\mathrm{HBV}$ antigens in isolated hepatocytes and autologous
lymphocyte cytotoxicity in patients with chronic HBV infection. Hepatology 1984; 4: 63-7.

54 Vento S, Hegarty JE, Alberti A, et al. T-lymphocyte sensitisation to hepatitis $\mathrm{BcAg}$ and $\mathrm{T}$ cell-mediated unresponsiveness to hepatitis HBsAg in hepatitis B virus-
related chronic liver disease. Hepatology 1985; 5: 192-7.

55 Nouri-Aria KT, Hegarty JE, Alexander GJM, Eddleston ALWF, Williams R. Effect of corticosteroids on suppressor-cell activity in 'autoimmune' and viral chronic active hepatitis. N Engl F Med 1982; 307: 1301-4.

56 Nouri-Aria KT, Donaldson PT, Hegarty JE, Eddleston ALWF, Williams R. HLA A1-B8-DR3 and suppressor cell function in first-degree relatives of patients with autoimmune chronic active hepatitis. F Hepatol 1985; 1 : 235 41.

57 Nouri-Aria KT, Hegarty JE, Alexander GJM, Eddleston ALWF, Williams $R$. IgG production in 'autoimmune' chronic active hepatitis. Effect of prednisolone on $T$ and $B$ lymphocyte function. Clin Exp Immunol 1985; 61: 290-6.

58 McFarlane IG, Eddleston ALWF. Chronic active hepatitis. In: Targan SR, Shanahan F, eds. Immunology and immunopathology of the liver and gastrot

59 Prince HE, Ettenger RB, Dorey FJ, et al. Azathioprine suppression of natural killer activity and antibodydependent cellular cytotoxicity in renal transplant recipients. $\mathcal{F}$ Clin Immunol 1984; 4: 312-8.

60 Pedersen BK, Beyer JM. A longitudinal study of the influence of azathioprine on natural killer cell activity. Allergy 1986; 41: 286-9.

61 Czaja AJ, Summerskill WHJ. Chronic hepatitis. To treat or not to treat? Med Clin North Am 1978; 62: 71-85.

62 Hegarty JE, Nouri-Aria KT, Portmann B, Eddleston ALWF, Williams R. Relapse following treatment withdrawal in patients with autoimmune chronic active hepatitis. Hepatology 1983; 3: 685-9.

63 Hegarty JE, Nouri-Aria KT, Eddleston ALWF, Williams R. Controlled trial of a thymic hormone extract (Thy-
mostimulin) in 'autoimmune' chronic active hepatitis. Gut mostimulin) in 'auto

64 Stellon AJ, Hegarty JE, Portmann B, Williams R. Randomised controlled trial of azathioprine withdrawal in autoimmune chronic active hepatitis. Lancet 1985; i: 668 70 .

65 Mackay IR. Chronic hepatitis: effect of prolonged immunosuppressive treatment and comparison of aza-

66 Stellon AJ, Keating JJ, Johnson PJ, McFarlane IG, Williams $R$. Maintenance of remission in autoimmune chronic active hepatitis with azathioprine after corticosteroid withdrawal. Hepatology 1988; 8: 781-4.

67 McFarlane IG, Hegarty JE, McSorley CG, McFarlane BM Williams $R$. Antibodies to liver specific protein predict outcome of treatment withdrawal in autoimmune chronic active hepatitis. Lancet 1984; ii: $954-6$.

68 Keating JJ, O'Brien CJ, Stellon AJ, et al. Influence of aetiology, clinical and histological features on survival in chronic active hepatitis. An analysis of 204 patients. $Q \mathcal{F}$ Med 1987; 62: 59-66.

69 Wang KW, Czaja AJ. Hepatocellular carcinoma in corticosteroid treated autoimmune chronic active hepatitis. Hepatology 1988; 8: 1679-83.
70 Johnson PJ, McFarlane IG, McFarlane BM, Williams R. Autoimmune features in patients with idiopathic chronic active hepatitis who are seronegative for conventional autoantibodies. F Gastroenterol Hepatol 1990; 5: 244-51.

71 McFarlane IG, McFarlane BM, Major GN, Tolley P, Williams R. Identification of the hepatic asialoglycoprotein receptor (hepatic lectin) as a component of liver specific membrane lipoprotein (LSP). Clin Exp Immunol 1984; 55: 347-54.

72 McSorley CG, Isaac JE, McFarlane BM, McFarlane IG, Williams R. Production of murine monoclonal antibodies against a liver-specific, species cross-reactive antigen in the against a liver-specific, species cross-reactive antigen in the liver-specific lipoprote

73 McFarlane IG. Hepatic clearance of serum glycoproteins. Clin Sci 1983; 64: 127-35.

74 McFarlane BM, McSorley CG, Vergani D, McFarlane IG, Williams R. Serum autoantibodies reacting with the hepatic asialoglycoprotein receptor protein (hepatic lectin) in acute and chronic liver disorders. F Hepatol 1986; 3: 196205.

75 Treichel U, Poralla T, Hess G, Manns M, Meyer zum Buschenfelde KH. Autoantibodies to human Buschenfelde KH. Autoantibodies to human asialoglycoprotein receptor in autoim
hepatitis. Hepatology 1990; 11: 606-12.

76 Vento S, McFarlane BM, McSorley CG, et al. Liver autoreactivity in acute virus $A, B$ and non- $A$, non-B hepatitis. f Clin Lab Immunol 1988; 25: 1-7.

77 Bedlow AJ, Donaldson PT, McFarlane BM, Lombard M, McFarlane IG, Williams R. Autoreactivity to hepatocellular antigens in primary biliary cirrhosis and primary sclerosing cholangitis. F Clin Lab Immunol 1989; 30: 1039.

78 Vento S, Hegarty JE, Bottazzo GF, Macchia E, Williams R, Eddleston ALWF. Antigen-specific suppressor cell function in autoimmune chronic active hepatitis. Lancet 1984; i: $1200-4$

79 Vento S, O'Brien CJ, McFarlane BM, McFarlane IG Eddleston ALWF, Williams R. T-lymphocyte sensitization to hepatocyte antigens in autoimmune chronic active hepatitis and primary biliary cirrhosis. Evidence for different underlying mechanisms and different antigenic determinants as targets. Gastroenterology 1986; 91: 810-7.

80 O'Brien CJ, Vento S, Donaldson PT, et al. Cell-mediated immunity and suppressor T-cell defects to liver-derived antigens in families of patients with autoimmune chronic active hepatitis. L ancet 1986; i: 350-3.

81 Vento S, O'Brien CJ, McFarlane IG, Williams R, Eddleston ALWF. T-cell inducers of suppressor lymphocytes contro liver-directed autoreactivity. Lancet 1987; i: 886-8.

82 Mills CT, Lee E, Perrillo R. Relationship between histology, aminotransferase levels, and viral replication in chronic hepatitis B. Gastroenterology 1990; 99: 519-24.

83 McFarlane BM, Sipos J, Gove CD, McFarlane IG, Williams $R$. Antibodies against the hepatic asialoglycoprotein receptor perfused in situ preferentially attach to periportal liver cells in the rat. Hepatology 1990; 11: 408-15.

84 Daniels CK, Smith KM, Schmucker DL. Asialoorosomucoid hepatobiliary transport is unaltered by the loss of liver asialoglycoprotein receptors in aged rats. Proc Soc Exp Biol Med 1987; 186: 246-50.

$85 \mathrm{McFarlane}$ IG. Autoimmunity and hepatotropic viruses. Semin Liver Dis 1991; 11: 223-33.

86 Koretz RL, Suffin SC, Gitnick GL. Post transfusion chronic liver disease. Gastroenterology 1976; 71: 797-803.

87 Omata M, Iwama S, Sumida M, et al. Clinico-pathological study of acute non-A, non-B post-transfusion hepatitis: histological features of liver biopsies in acute phase. Liver 1981; 1: 201-8.

88 Vanstapel MJJ, van Steenbergen W, De Wolf-Peeters D, et al. Prognostic significance of piecemeal necrosis in acute viral hepatitis. Liver 1983; 3: 46-57.

89 Scheuer PJ. Viral hepatitis. In: MacSween RNM, Anthony PP, Scheuer PJ, eds. Pathology of the liver. Edinburgh: Churchill-Livingstone, 1987: 202-23.

90 Dienes HP, Popper H, Arnold W, Lobeck H. Histologic Popatitis non-A, non-B. Hepatology 1982; 2: 562-71.

91 Poralla T, Hutteroth TH, Meyer zum Buschenfelde $\mathrm{KH}$. Cellular cytotoxicity against autologous hepatocytes in
acute and chronic non-A, non-B hepatitis. Gut 1984; 25 : 114-20.

92 Mondelli M, Alberti A, Tremolada F, et al. In vitro cellmediated cytotoxicity for autologous liver cells in chronic non-A, non-B hepatitis. Clin Exp Immunol 1986; 63: 14755.

93 Tage-Jensen U, Permin H, Hardt F, et al. Circulating autoantibodies in patients with acute viral hepatitis. Scand $\mathcal{F}$ Gastroenterol 1980; 15: 229-35.

94 Esteban JI, Esteban R, Viladomiu L, et al. Hepatitis C virus antibodies among risk groups in Spain. Lancet 1989; ii: 294-6.

95 Lenzi M, Ballardini G, Fusconi $M$, et al. Type 2 autoimmune hepatitis and hepatitis C virus infection. Lancet 1990; 335 258-9.

96 McFarlane IG, Smith H, Johnson PJ, Bray G, Vergani D, Williams $\mathrm{R}$. Hepatitis $\mathrm{C}$ virus antibodies in chronic active hepatitis: pathogenetic factor or false-positive result? Lancet 1990; 335: 754-7.

97 Gray JJ, Wreghitt TG, Friend PJ, Wight DGD, Sundaresan $\mathrm{V}$, Calne RY. Differentiation between specific and nonspecific hepatitis $\mathrm{C}$ antibodies in chronic liver disease. Lancet 1990; 335: 609-10.

98 Ikeda Y, Toda G, Hashimoto N, Kurokawa K. Antibody to 
superoxide dismutase, autoimmune hepatitis, and antibody tests for hepatitis C virus. Lancet 1990; 335: 1345-6. 99 Colombo M, Rumi MG, Mannucci PM. Specificity of hepatitis $\mathrm{C}$ antibody Elisa in patients with haemophilia. Lancet 1990; 335: 1345.

100 Theilmann L, Blazek M, Goeser T, Gmelin K, Kommerell $B$, Fiehn W. False-positive anti-HCV tests in rheumatoid arthritis. Lancet 1990; 335: 1345-6.

101 Boudart D, Lucas JC, Muller JY, LeCarrer D, Planchon B, Harousseau JL. False-positive hepatitis $C$ virus antibody tests in paraproteinaemia. Lancet 1990; 336: 63 .

102 Feighery C, McDonald GSA, Greally JF, Weir DG. Histogical and immunological investigation of liver-specific LSP) immunized rabbits compared with patients with liver disease. Clin Exp Immunol 1981; 45: 143-51.

103 Bartholomaeus WN, Reed WD, Joske RA, Shilkin KB. Autoantibody responses to liver-specific lipoprotein in mice. Immunology 1981; 43: 219-26.

104 Uibo RM, Helin KJ, Krohn KJE. Immunological reactions to liver specific membrane lipoprotein (LSP) in experimento liver specific membrane lipoprotein (LSP) in experimental autoimmune liver

105 Kuriki J, Murakami H, Kakumu S, et al. Experimental autoimmune hepatitis in mice after immunization with syngeneic liver proteins together with the polysaccharide of Klebsielle pneumoniae. Gastroenterology 1983; 84: 596603.

106 Bartholomaeus WN, Shellam GR, Allan JE, Reed WD, Joske RA. Autoantibodies to liver-specific lipoprotein following hepatitis induced by mouse cytomegalovirus. Clin Exp Immunol 1983; 52: 89-97.

107 Bartholomaeus WN, O'Donoghue H, Reed WD. Thymusdependence of autoantibody responses to liver specific dependence of autoantibody responses to liver specific
lipoprotein in the mouse. Clin Exp Immunol 1984; 55: 541lipopro

108 Vento S, McFarlane BM, Garogano G, et al. Serial study of liver-directed autoantibodies and autoreactive T-lymphocytes in acute viral hepatitis B. 7 Autoimmunity 1988; 1 : 299-307.

109 Mori Y, Mori T, Yoshida H, et al. Study of cellular immunity in experimental autoimmune hepatitis in mice. Clin Exp Immunol 1984; 57: 85-92.

110 Mori Y, Mori T, Ueda S, et al. Study of cellular immunity in experimental autoimmune hepatitis in mice: transfer of spleen cells sensitized with liver proteins. Clin Exp Immunol 1985; 61: 577-84.

111 Mori T, Mori Y, Yoshida H, et al. Cell-mediated cytotoxicity of sensitized spleen cell against target liver cells- in vivo and of sensitized spleen cell against target liver cells- in vivo and in vitro study with a mouse model of experim

112 Ogawa $M$, Mori Y, Mori T, et al. Adoptive transfer of experimental autoimmune hepatitis in mice - cellular interaction between donor and recipient mice. Clin Exp Immunol 1988; 73: 276-82.

113 Lohse AW, Manns M, Dienes HP, Meyer zum Buschenfelde KH, Cohen IR. Experimental autoimmune hepatitis: disease induction, time course and T-cell reactivity. Hepatology 1990; 11: 24-30.

114 Wen L, Peakman M, Lobo-Yeo A, et al. Evidence that circulating activated $\mathrm{T}$ lymphocytes direct the immune attack on the liver cell in autoimmune chronic active hepatitis. Lancet 1990; 336: 1527-30.

115 Lohr H, Treichel U, Poralla T, Meyer zum Buschenfelde KH, Fleischer B. The human hepatic asialoglycoprotein receptor is a target antigen for liver infiltrating $\mathrm{T}$ cells in receptor is a target antigen for liver in and primary biliary autoimmune chronic active hepatitis and
cirrhosis. Hepatology 1990; 12: 1314-20.

116 Cooksley WGE, Bradbear RA, Robinson W, et al. The prognosis of chronic active hepatitis without cirrhosis in relation to bridging necrosis. Hepatology 1986; 6: 345-8.

117 Manns M, Griffin KJ, Sullivan KF, et al. Molecular mimicry between intermediate early protein (IE175) of herpes simplex virus and cytochrome P450 dbl (IID6), a major autoantigen in autoimmune hepatitis [Abstract]. Hepatology 1990; 12: 907.

118. Lenzi M, Johnson PJ, McFarlane IG, et al. Antibodies to hepatitis $C$ virus in autoimmune liver disease: evidence for geographical heterogeneity. Lancet 1991 (in press) 